\title{
ASPEK GEOARKEOLOGI TERHADAP STRATEGI SUBSISTENSI MASYARAKAT DI PESISIR SELATAN BELITUNG DARI ABAD KE-19 SAMPAI AWAL ABAD KE-20 MASEHI
}

\section{GEOARCHAEOLOGICAL ASPECTS OF THE COMMUNITY SUBSISTENCE STRATEGY IN THE SOUTH COAST OF BELITUNG FROM THE 19th TO EARLY 20th CENTURY}

\author{
Aryandini Novita1 dan Ari Mukti Wardoyo Adi² \\ ${ }^{1}$ Balai Arkeologi Sumatera Selatan, Jl Kancil Putih, Demang Lebar Daun Palembang, Indonesia; posel: novitaaryandini@gmail.com \\ 2Program Studi Arkeologi Universitas Jambi, Jl Raya Jambi-Muara Bulian km 15 Mendalo Indah, Muaro Jambi, Indonesia; posel: \\ ariwardoyo@unja.ac.id
}

\begin{abstract}
Abstrak. Manusia dapat melakukan berbagai aktivitas untuk bertahan hidup sesuai dengan lingkungan fisik di sekitarnya, dan pada akhirnya menyisakan bentanglahan yang sedemikian rupa saat ini. Dalam upaya bertahan hidup, strategi subsistensi merupakan faktor paling mendasar dalam aktivitas kehidupan manusia. Rekonstruksi aktivitas manusia dalam menjalankan strategi subsistensinya pada masa lalu dapat dilakukan dengan mengkaji lingkungan fisik dan tinggalan arkeologi yang tersisa. Pulau Belitung memiliki peranan penting pada masa kolonial karena kondisi geografisnya. Potensi tambang timahnya mampu menarik perhatian pemerintah Hindia-Belanda untuk mulai melakukan eksploitasi pada abad ke-19 Masehi. Penelitian ini bertujuan untuk memahami pola aktivitas masyarakat di pesisir selatan Pulau Belitung dalam menjalankan strategi subsistensinya dari abad ke-19 hingga awal abad ke-20 Masehi, dengan menggunakan pendekatan geoarkeologi. Variabel yang digunakan sebagai dasar analisis adalah topografi, morfologi, bentuklahan, serta distribusi situs arkeologi dan jenis temuan arkeologi yang ditinggalkan. Hasil penelitian ini menunjukkan bahwa pola aktivitas masyarakat di pesisir selatan Pulau Belitung melibatkan dua ekosistem, yakni perairan dan kelekak. Dua ekosistem tersebut memiliki kedudukan penting dalam kehidupan sehari-hari masyarakat di pesisir selatan Pulau Belitung, di mana tambang timah merupakan produk yang mayoritas dieksploitasi.
\end{abstract}

Kata kunci: Strategi subsistensi, Lingkungan alam, Pesisir selatan Belitung, Bentanglahan, Tambang timah, Geoarkeologi, Ekosistem perairan

\begin{abstract}
Humans can carry out various activities to survive following the physical environment around them, and eventually, leaving such landscapes as it is today. To survive, the subsistence strategy is the most fundamental factor in human life activities. The reconstruction of human activities in carrying out their subsistence strategy in the past can be done by examining the physical environment and the remaining archaeological remnants. Pulau Belitung played an important role during the colonial period due to its geographical conditions. The potential for tin mining was able to attract the attention of the Dutch East Indies government to start exploiting it in the $19^{\text {th }}$ century. This study aims to comprehend the pattern of community activity on the southern coast of Pulau Belitung in carrying out its subsistence strategy from the $19^{\text {th }}$ to the early $20^{\text {th }}$ century, using a geoarcheological approach. The variables used as the basis for the analysis are topography, morphology, landform, and distribution of archaeological sites and the types of archaeological items left behind. The results of this study indicate that the pattern of community activity on the southern coast of Pulau Belitung Island involves two ecosystems, which are aquatic and kelekak. The two ecosystems have an important position in the daily life of the people on the southern coast of Pulau Belitung, where tin mining is the product that is mostly exploited.
\end{abstract}

Keywords: Subsistence strategy, Natural environment, South coast of Belitung, Landscape, Tin mining, Geoarcheology, Aquatic ecosystem

\section{PENDAHULUAN}

Aktivitas manusia dalam menjalankan strategi subsistensinya dapat menyebabkan terjadinya perubahan fisik pada lanskap serta memberi pengaruh terhadap daya dukung lingkungan, terutama yang berkaitan dengan sumber daya. Hal tersebut dapat disebabkan oleh manusia yang tidak bertindak secara pasif dalam berinteraksi dengan lingkungan fisiknya, melainkan lebih bersifat timbal balik (Raharja dkk. 2016; Wardani dkk. 2019; Yanti dan Ibrahim 2018). Hubungan yang dinamis ini menunjukkan bahwa manusia tidak hanya beradaptasi dengan lingkungan fisiknya, tetapi juga berupaya aktif untuk 
mengubahnya sesuai kebutuhan (Mus 2016; Zuriyani 2016).

Lingkungan fisik memiliki peran penting sebagai penyedia sumber daya untuk kebutuhan hidup manusia. Oleh karena itu, secara langsung ataupun tidak, dalam berbagai kebudayaan, manusia telah mengembangkan konsep-konsep yang bertujuan untuk menjaga keseimbangan hubungan antara dirinya dan lingkungannya. Manusia memiliki konsep filosofis dan kepercayaan yang berkaitan dengan lingkungan di sekitarnya (Ode, Sahida, dan Sifatu 2001; Fahmi 2017). Berdasarkan hal tersebut, dapat dikatakan bahwa lingkungan fisik selalu memiliki makna tertentu bagi kehidupan manusia (Fitrahayunitisna 2019; Puspawati 2016). Pemaknaan terhadap lingkungan fisik tersebut dapat tecermin pada mitos-mitos mengenai elemen lingkungan fisik seperti gunung, batu, pohon atau sumber air (Fahmi, Gunardi, dan Mahzuni 2017).

Strategi subsistensi yang dilakukan oleh masyarakat di wilayah nusantara pada masa lalu selalu menarik untuk dikaji. Apalagi dengan kondisi lingkungan fisik yang berbeda antara satu pulau dan pulau lain. Pulau Belitung merupakan salah satu pulau dengan karakteristik lingkungan fisik yang unik dan cukup penting dalam historiografi Indonesia. Pulau ini terkenal dengan gugusan batu granit dan pantai-pantainya yang indah. Sejak abad ke-7 Masehi (M), Pulau Belitung, bersama dengan Pulau Bangka, diduga pernah menjadi penghasil timah yang merupakan komoditi utama Sriwijaya (Pradjoko dan Utomo 2013; Suprapto 2008; Vlekke 2008). Nama 'Pulau Belitung' makin dikenal dalam berita Cina ketika menjadi tempat persinggahan pasukan Mongol pada waktu melakukan ekspedisi ke Pulau Jawa pada tahun 1292-1293 (Bade 2002; Groeneveldt 2018). Pulau Belitung kemudian makin berkembang menjadi pusat penambangan timah pada periode Kesultanan Palembang dan pemerintah kolonial Belanda hingga awal abad ke20 M (Erman 2009; Suprapto 2008).

Panjangnya kronologi sejarah Pulau Belitung tersebut tentu saja melibatkan masyarakat yang memiliki strategi subsistensi tertentu. Interaksi antara manusia dan lingkungan fisik ataupun antara manusia dan manusia lain, baik secara internal maupun eksternal jelas terjadi dalam rangka pemenuhan kebutuhan hidup. Bentuk subsistensi yang dipilih oleh masyarakat di Pulau Belitung sebagai penghasil timah pada masa lalu kemudian menjadi pertanyaan besar dan memerlukan penelusuran lebih dalam untuk menjawabnya. Jejak-jejak tinggalan arkeologi memang secara tidak langsung dapat menggambarkan strategi subsistensi ini. Namun demikian, pendekatan ilmu di luar sejarah dan arkeologi tentu saja diperlukan untuk memperkaya sudut pandang dalam upaya merekonstruksi strategi subsistensi tersebut.

Salah satu ilmu pengetahuan yang dapat digunakan sebagai pendekatan untuk mengkaji mengenai interaksi antara manusia dan lingkungan fisiknya adalah geografi. IImu ini, selain memfokuskan kajiannya terhadap fenomena dan proses bumi, juga mempelajari mengenai keterkaitan antara lingkungan fisik dan manusia. Salah satu caranya ialah dengan mengidentifikasi unit-unit ruang aktivitas manusia pada kurun waktu tertentu (Ashari 2014, 2015). Dalam penelitian arkeologi, pendekatan geografi kemudian dapat digunakan untuk menjelaskan korelasi antara aspek geomorfologi dan aktivitas kebudayaan yang terjadi pada masa lalu (Giaime, Marriner, dan Morhange 2019; Goldberg dan Aldeias 2018; Kidder dan Liu 2017). Lebih lanjut, pendekatan ilmu geografi dalam kajian arkeologi yang dapat digunakan untuk menjelaskan proses alami dan pengaruh manusia dalam mengubah lanskap ini kemudian dikenal dengan istilah geoarkeologi (Butzer 2006; French 2003).

Topografi merupakan satu dari beberapa aspek yang dapat digunakan sebagai unit analisis dalam geoarkeologi. Dalam kajian ini, informasi topografi di suatu wilayah dapat membantu menjelaskan pengaruh bentang lahan dan bentuk lahan terhadap distribusi tinggalan arkeologi sebagai hasil dari aktivitas manusia (Amato dkk. 2018; Christiansen dkk. 2016; Contreras 2017; Giaime dkk. 2019). Informasi tentang topografi dalam kaitannya dengan geomorfologi dapat meliputi morfologi, morfogenesis, morfokronologi, dan morfoasosiasi atau morfoarrangement (Van Zuidam 1979). Aspek-aspek topografi dan geomorfologi tersebut juga dapat digunakan untuk mengetahui potensi sumber daya, baik sumber daya lahan, sumber daya air maupun sumber daya mineral yang terkandung dalam suatu wilayah (Key, Lieber, dan Teagle 2020; Roos dan Wells 2017; Storozum dkk. 2019). Potensi sumber daya inilah yang menjadi faktor utama bagi manusia untuk beraktivitas dalam suatu wilayah tertentu dan dalam kurun waktu tertentu, sehingga menyisakan 
tinggalan arkeologi di dalamnya (Bachofer dkk. 2018; Kelley dan Sanger 2017; Storozum dkk. 2019). Kedudukan dan peranan penting suatu wilayah terhadap suatu masyarakat dalam kerangka kebudayaan yang lebih luas juga dapat ditentukan dari potensi tersebut.

Tulisan ini bertujuan untuk memberikan gambaran tentang kondisi topografi di pesisir selatan Pulau Belitung dan kaitannya dengan aktivitas masyarakat di wilayah tersebut pada abad ke-19 $\mathrm{M}$ hingga awal abad ke-20 $\mathrm{M}$, dengan menggunakan pendekatan geoarkeologi.

Pesisir selatan Pulau Belitung menarik untuk dikaji mengingat bahwa wilayah ini masih jarang diteliti. Padahal masyarakat di wilayah ini pada kurun waktu tersebut telah memiiki ruang aktivitas, sebagaimana dapat ditunjukkan dengan adanya tinggalan arkeologi yang terdistribusi pada tempattempat tertentu, dan memiliki korelasi satu sama lain. Penjelasan mengenai hubungan timbal balik antara manusia dan faktor lingkungan fisik akan dibahas berdasarkan unit aktivitasnya dalam lingkup situs, serta akan dijabarkan secara lebih eksplisit dalam lingkup kawasan.

\section{METODE}

Penelitian ini menggunakan data dari hasil penelitian arkeologi di wilayah pesisir selatan Pulau Belitung yang dilakukan oleh Balai Arkeologi Sumatera Selatan pada tahun 2018. Secara administratif, wilayah penelitian berada dalam Kecamatan Membalong, yang meliputi Desa Membalong, Desa Mentigi, Desa Tanjung Rusa, dan Desa Gunung Riting. Studi area terletak pada koordinat antara $3^{\circ} 2 ' 39,8^{\prime \prime}-3^{\circ} 23^{\prime} 11^{\prime \prime}$ Lintang Selatan (LS) dan 107 $31^{\prime} 43,4^{\prime \prime}$ - 107'55'6,5" Bujur Timur (BT; Novita dkk. 2018; Gambar 1).

Pada penelitian 2018, proses pengumpulan data dilakukan dengan metode survei lapangan dan pemetaan. Pengumpulan data tidak hanya di situssitus arkeologi yang berada di daratan, tetapi juga situs-situs arkeologi yang terdapat di perairan, baik lingkungan pantai maupun di bawah air (Novita dkk. 2018).

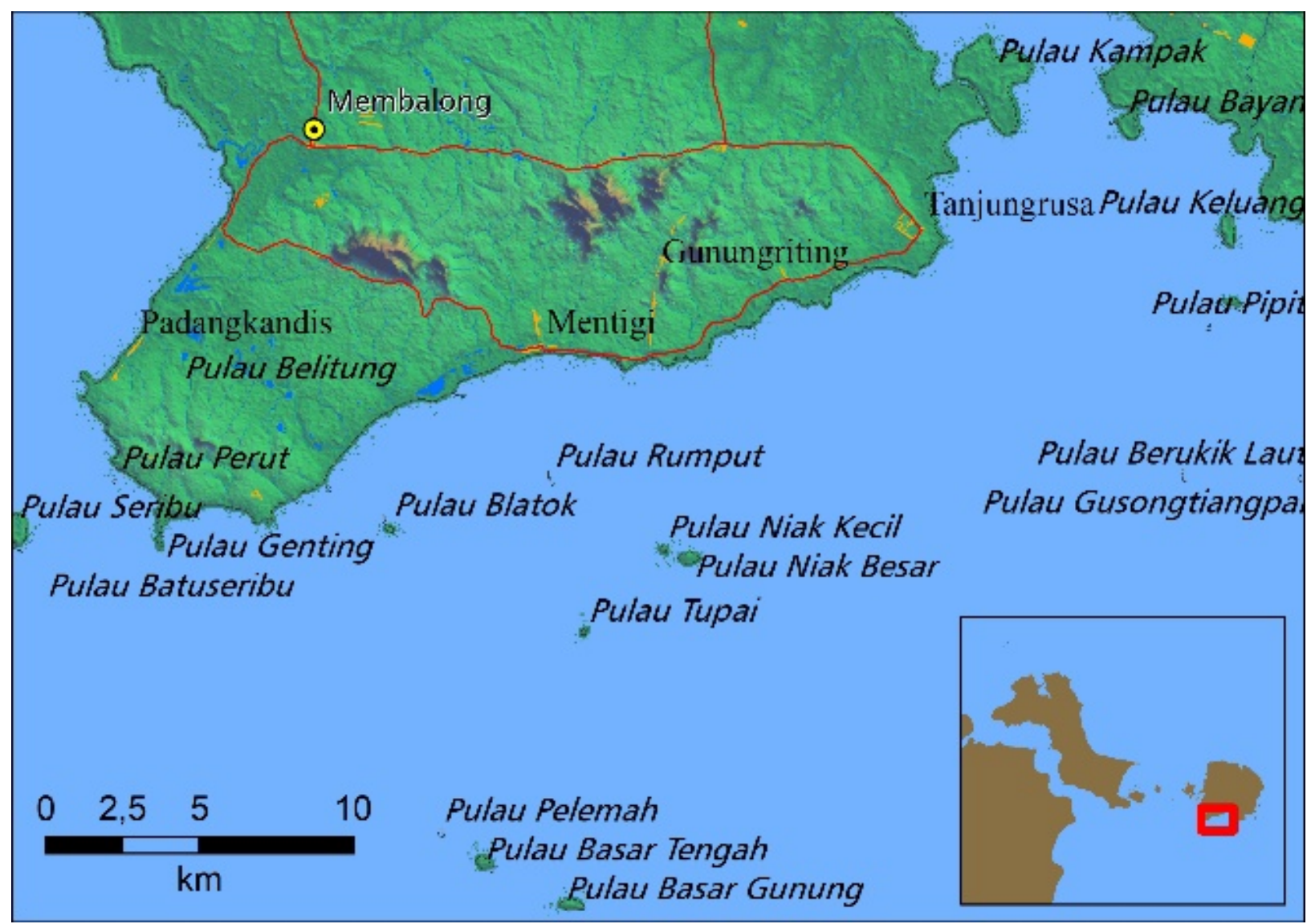

Sumber: Balar Sumsel 2018

Gambar 1 Wilayah Penelitian Peran Pulau Belitung Bagian Selatan dalam Jalur Perdagangan pada Awal Abad ke-20 M 
Data yang diperoleh dari kegiatan lapangan 2018, kemudian dianalisis sesuai dengan tujuan dari tulisan ini, yaitu mencari keterkaitan antara kondisi topografi wilayah dan pola aktivitas masyarakat di dalamnya yang tercermin dari tinggalan arkeologi. Pengamatan secara mendalam terhadap atribut-atribut keruangan ini dalam pelaksanaannya juga memperhatikan aspek transformasi dan tafonomi, sehingga dapat meminimalkan terjadinya kesalahan interpretasi dalam penarikan kesimpulan (Amato dkk. 2018; Volkmann 2018).

Pengamatan dilakukan dengan cara melihat keterkaitan tinggalan arkeologi dengan topografi lahan lokasi tinggalan arkeologi tersebut ditemukan. Hal ini ditujukan untuk memberikan gambaran tentang pengaruh bentang lahan dan bentuk lahan terhadap sebaran data arkeologi di wilayah penelitian (Amato dkk. 2018; Volkmann 2018). Dengan demikian, dapat dilihat gambaran aktivitas para pemukim yang tinggal di lokasi penelitian pada masa lalu, dalam memanfaatkan ruang-ruang aktivitas di wilayah tersebut (Amato dkk. 2018; Volkmann 2018).

Instrumen yang digunakan dalam proses analisis data adalah perangkat sistem informasi geografi. Analisis dilakukan dalam dua tahap dengan menerapkan metode overlay terhadap sejumlah peta tematik, yang kemudian dapat memperlihatkan hubungan spasial antarvariabel (Amato dkk. 2018; Volkmann 2018).

Tahap pertama dalam proses analisis adalah memetakan seluruh situs arkeologi berdasarkan jenis temuannya di wilayah penelitian agar terlihat pola persebarannya. Tahap yang kedua adalah membuat overlay peta sebaran situs dengan peta topografi wilayah penelitian (Amato dkk. 2018; Volkmann 2018). Peta topografi yang dimaksud merupakan hasil pengolahan dari beberapa sumber data. Data topografi daratan diperoleh dari data Digital Elevation Model Nasional (DEMNAS) dengan resolusi 0.27 -arcsecond. Data topografi situs yang berada di wilayah perairan diakuisisi dengan metode singlebeam echosounder (Wijonarko, Sasmito, dan Nugraha 2016). Kedua jenis data topografi ini kemudian diolah menjadi peta topografi yang dapat menunjukkan kelas ketinggian dan kelas lereng, baik di darat maupun di dasar laut. Akan tetapi, oleh karena terdapat perbedaan hasil resolusi antara peta topografi daratan dan peta topografi dasar laut, proses mosaik tidak dapat dilakukan pada kedua peta tersebut.

\section{HASIL DAN PEMBAHASAN}

\section{Hasil Analisis}

Data situs arkeologi yang direkam dalam penelitian kali ini ada tujuh (lampiran: Gambar 14). Tiga situs berada di wilayah perairan, yaitu situssitus Karang Kennedy, Pulau Kampak, dan Demaga Tanjung Kiras. Empat situs yang berada di wilayah daratan, termasuk Makam Membalong, Kelekak Ketembab, Kelekak Luday, dan Kelekak Balai Ulu. Tinggalan arkeologi yang ditemukan dalam penelitian ini dikategorikan menjadi empat jenis, yaitu artefak, ekofak, struktur dan situs. Artefak yang dianalisis berupa keramik (Gambar 2), kaca (Gambar 3), logam (Gambar 4), gerabah (Gambar 5) dan kayu (Gambar 6). Ekofak (Gambar 7) yang dianalisis berupa sisa fauna yang menjadi konsumsi masyarakat di lokasi penelitian berupa kerang dan siput. Struktur dan situs yang dianalisis berupa makam (Gambar 8) dan tempat penimbunan balok batu (Gambar 9), yang diduga merupakan bagian dari pembuatan dermaga.

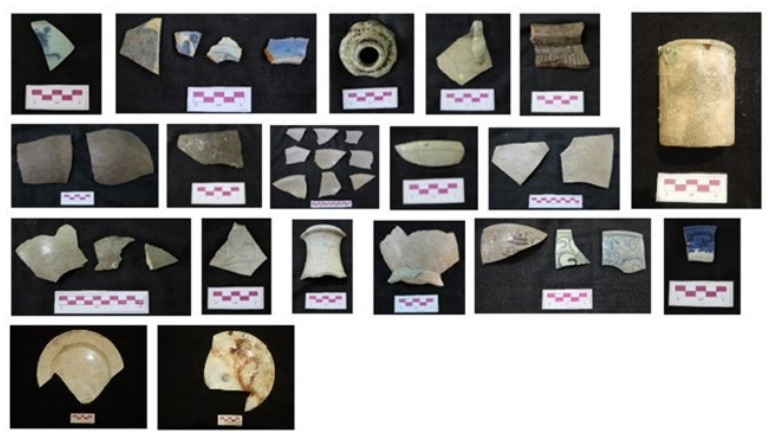

Sumber: Balar Sumsel 2018

Gambar 2 Variasi Temuan Keramik Hasil Penelitian

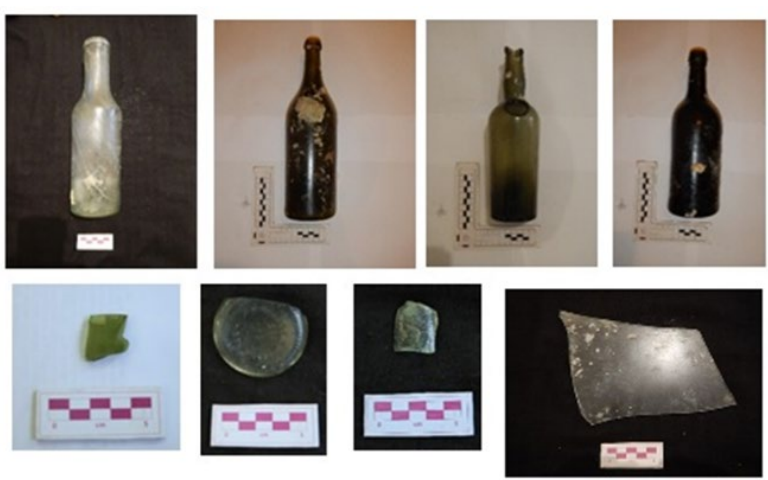

Sumber: Balar Sumsel 2018

Gambar 3 Variasi Temuan Kaca Hasil Penelitian 

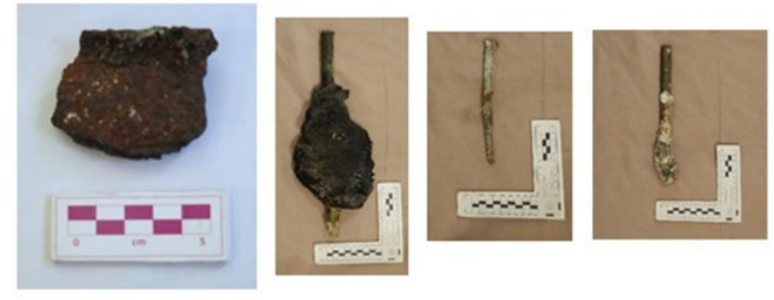

Sumber: Balar Sumsel 2018

Gambar 4 Variasi Temuan Logam Hasil Penelitian
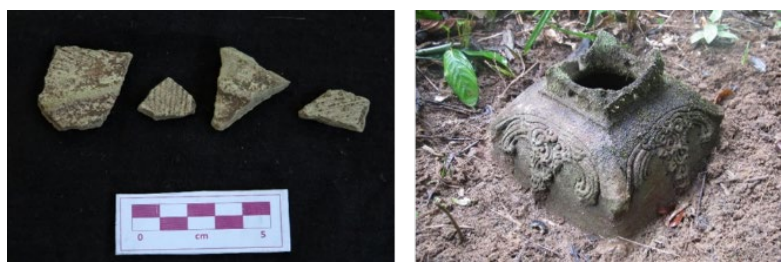

Sumber: Balar Sumsel 2018

Gambar 5 Variasi Temuan Gerabah Hasil Penelitian

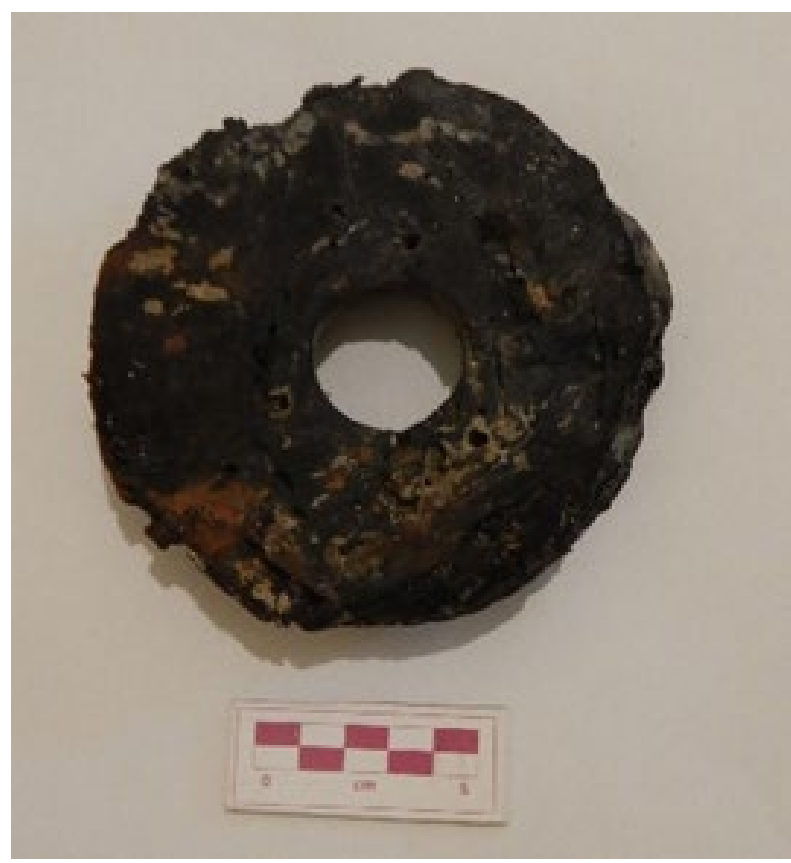

Sumber: Balar Sumsel 2018

Gambar 6 Temuan Kayu Hasil Penelitian
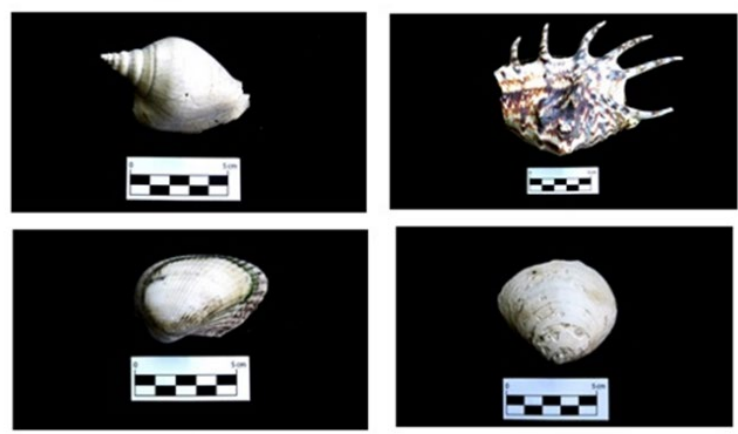

Sumber: Balar Sumsel 2018

Gambar 7 Variasi Temuan Ekofak Hasil Penelitian
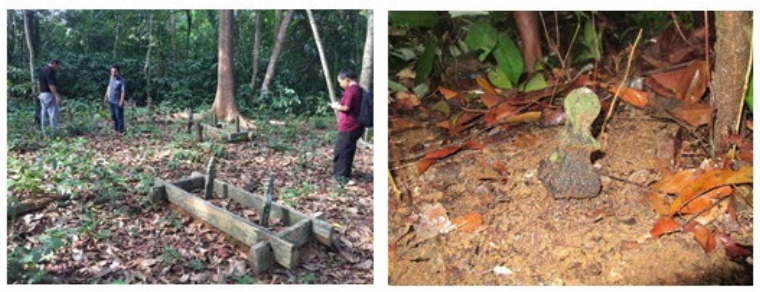

Sumber: Balar Sumsel 2018

Gambar 8 Variasi Struktur Makam Hasil Penelitian
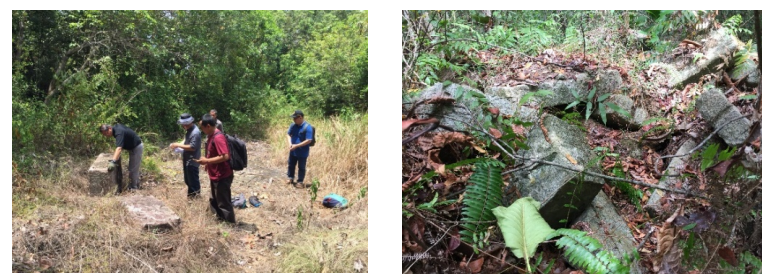

Sumber: Balar Sumsel 2018

Gambar 9 Temuan Timbunan Batu yang diduga Bahan Dermaga di Situs Tanjung Kiras

Situs Karang Kennedy merupakan satusatunya dari sekian situs dalam penelitian ini yang merupakan situs bawah air, dengan temuan sisa kapal karam. Situs Karang Kennedy berada di sebelah utara Pulau Basar Tengah. Pulau ini berjarak sekitar $15 \mathrm{~km}$ di sebelah selatan Pulau Belitung, sekitar satu jam berlayar dengan perahu dari dermaga Desa Mentigi. Pulau Basar Tengah dikelilingi oleh gosong karang yang luasnya diperkirakan hampir tiga kali luas pulau tersebut. Terumbu karang dan gosong karang di wilayah tersebut mempengaruhi karakter topografi dasar laut di sekitarnya. Pada umumnya, terumbu karang tumbuh pada kedalaman antara -11 meter bawah permukaan laut (mbpl) hingga $-14 \mathrm{mbpl}$. Pada kedalaman kurang dari satu meter, di wilayah perairan tersebut terdapat gosong karang. Di wilayah ini terdapat bekas lembah sungai purba yang merupakan tempat lapukan batuan granit terdeposisi, dan tempat bagian ini tidak ditumbuhi terumbu karang (Gambar 10).

Berdasarkan karakteristik lingkungan fisiknya, Pulau Basar Tengah yang berada di sekitar Situs Karang Kennedy, bersama dengan Pulau Basar Gunung dan Pulau Pelemah, terletak pada formasi batuan karang yang mengalami pengangkatan sehingga menjadi pulau. Formasi ini merupakan sisa ekosistem terumbu karang laut dangkal pada kala Pleistosen hingga Holosen awal. Lapisan ini diperkirakan juga tertimbun oleh pasir kuarsa hasil erosi dari bukit-bukit granit, seiring dengan penurunan ketinggian air laut pada kala itu. 
Secara geologis, lapisan terumbu karang tua Mentigi berada di atas satuan Aluvium yang berbatasan dengan satuan batuan Granit Adamelit Baginda, yang mendominasi Pulau Belitung bagian selatan (Romadhona 2016).

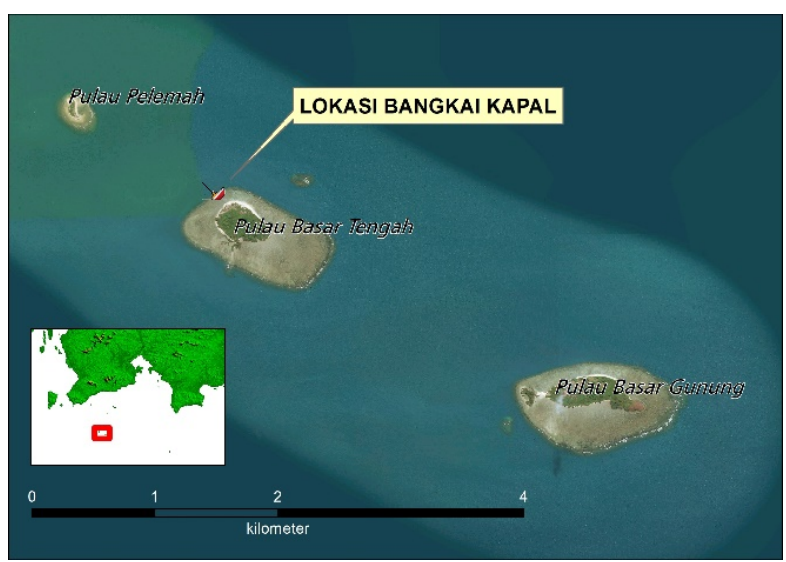

Sumber: Balar Sumsel 2018

Gambar 10 Lokasi Situs Karang Kennedy

Pemetaan dasar laut dengan singlebeam echosunder menunjukkan dasar laut bagian utara dan barat laut Pulau Basar Tengah berupa lembah yang dikelilingi terumbu karang. Lembah ini memiliki kedalaman $-17 \mathrm{mbpl}$. Lebar lembah sekitar 40-50 m dengan panjang $280 \mathrm{~m}$. Berdasarkan pengamatan dalam proses penyelaman untuk memvalidasi hasil pemetaan, di lembah tersebut terdapat lapisan lumpur. Lumpur tersebut terdeposit cukup tebal dan keberadaannya sangat dipengaruhi oleh arus air laut seperti tergambar pada peta topografi yang menunjukkan kontur dasar laut sekitar situs beserta penampang 3 dimensinya. Pada peta tersebut rona yang berwarna lebih gelap menunjukkan keberadaan terumbu karang yang terdapat di sekitar situs dimana makin ke dalam terumbu karang makin sedikit yang ditandai oleh rona yang makin cerah hingga dasar laut yang berupa pasir dan lumpur (Gambar 11).

Dasar perairan di Pulau Belitung bagian selatan memiliki topografi yang terdiri atas susunan batu karang yang terbentuk pada kala Pleistosen hingga Holosen awal. Dasar perairan ini terbentuk dari formasi batuan granit adamelit baginda yang ditumbuhi oleh terumbu karang. Selain itu, terdapat juga selingan formasi aluvium yang merupakan hasil endapan dari lapukan batuan granit tersebut. Di bagian permukaan laut terdapat pulau-pulau karang yang terbentuk dari singkapan batu karang. Pada awalnya pulau karang tersebut berupa gosong terumbu (patch reefs) yang muncul di permukaan dikarenakan muka air laut yang turun. Berdasarkan Peta Geologi Lembar Belitung tahun 1995 , terlihat adanya bentukan pulau-pulau karang di perairan Belitung bagian selatan, antara lain Pulau Selui, Pulau Kampak, Pulau Niak, Pulau Tupai, Pulau Pelemah, Pulau Basar Tengah, dan Pulau Basar Gunung (Baharuddin dan Sidarto 1995; Romadhona 2016).

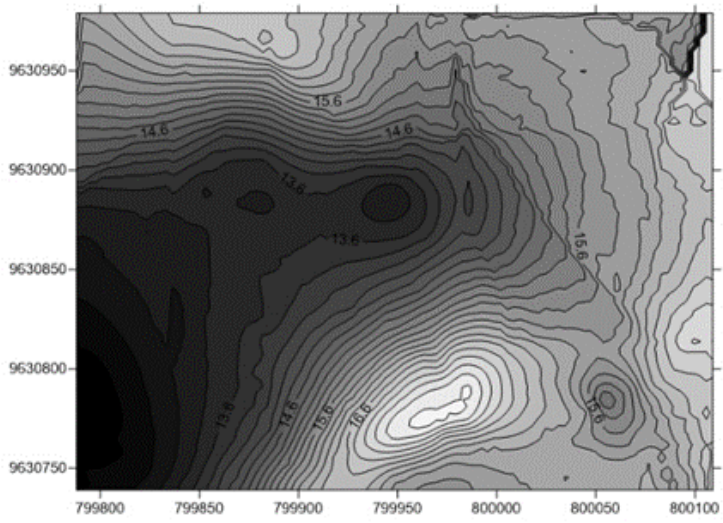

(a)

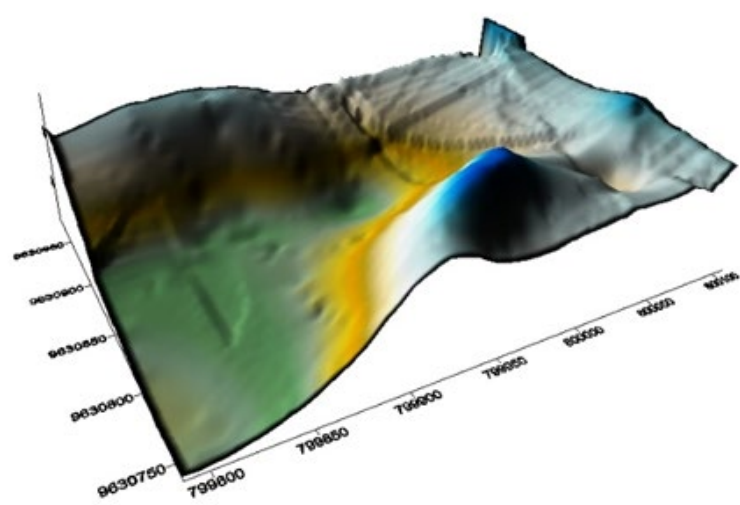

(b)

Sumber: Balar Sumsel 2018 (Gambar dan olah data oleh Yanto HM Manurung)

Gambar 11 Topografi Bawah Laut (a-b) di Situs Karang Kennedy dalam Bentuk Peta Kontur dan Penampang 3D

Selain situs Karang Kennedy, temuan arkeologi di lingkungan perairan juga dijumpai di situs Pulau Kampak. Di situs ini ditemukan deposit temuan artefak keramik dalam jumlah yang sangat besar dan dari periode yang relatif panjang, antara abad ke-10 M hingga ke-20 M. Keramik tersebut ada yang fragmentaris, dan ada yang masih utuh. Di samping temuan keramik, artefak-artefak kaca berupa botol juga banyak ditemukan di situs Pulau Kampak. Pada masa lalu, Pulau Kampak diduga 
kuat menjadi tempat penimbunan barang komoditi dari luar untuk sementara waktu sebelum masuk ke wilayah selatan Pulau Belitung. Hal ini diduga karena Pulau Kampak tidak mampu memberikan dukungan bagi kebutuhan harian karena pulau ini merupakan bentukan karang yang tidak memiliki cadangan air tanah. Pulau ini juga terletak di lingkungan perairan yang relatif tenang, karena berada di bagian dalam Teluk Balok.

Situs lain yang berlokasi di wilayah perairan adalah situs Tanjung Kiras. Lokasi situs ini diduga merupakan tempat yang akan digunakan sebagai dermaga. Beberapa temuan arkeologis yang masih dapat dijumpai saat ini adalah patok-patok batu yang ditemukan di sekitar pantai, sejumlah fragmen keramik asing, serta timbunan balok-balok batu granit dalam berbagai ukuran yang umumnya dijumpai sebagai dasar dermaga ataupun jetty. Balok-balok batu tersebut dijumpai sekitar $200 \mathrm{~m}$ ke arah utara dari pantai. Di sekitar tempat ini ditemukan juga dinding bekas galian batu granit. Pada jarak $600 \mathrm{~m}$ ke arah utara ditemukan juga makam Cina, yang kemungkinan memiliki kaitan erat dengan situs Tanjung Kiras.

Berbeda dengan lingkungan perairan, situssitus arkeologi di wilayah daratan terletak pada morfologi perbukitan dan lembah yang unik. Morfologi perbukitan dan lembah tersebut dibentuk oleh kemunculan batu-batu granit dalam bentuk bongkah-bongkah raksasa. Topografi lingkungan darat di wilayah penelitian terdapat pada ketinggian antara $+38-80$ meter atas permukaan laut (mapl), dan berupa lereng dengan kemiringan antara 5-25\% (Gambar 12). Batuan granit yang terdapat di Pulau Belitung ini merupakan bagian dari batuan dasar Indonesia bagian barat. Dari segi umur, batuan granit di wilayah selatan Pulau Belitung merupakan granit berumur Jura dengan formasi yang disebut satuan Granit Adamelit Baginda. Batuan granit di wilayah ini memiliki variasi warna abu-abu hingga kehijauan, dengan variasi butiran kasar hingga sangat kasar, mengandung banyak xenolit dan tidak ditemukan kandungan kasiterit. Kronologi absolut batuan ini sekitar 106-245 juta tahun (Priem dkk. 1975).

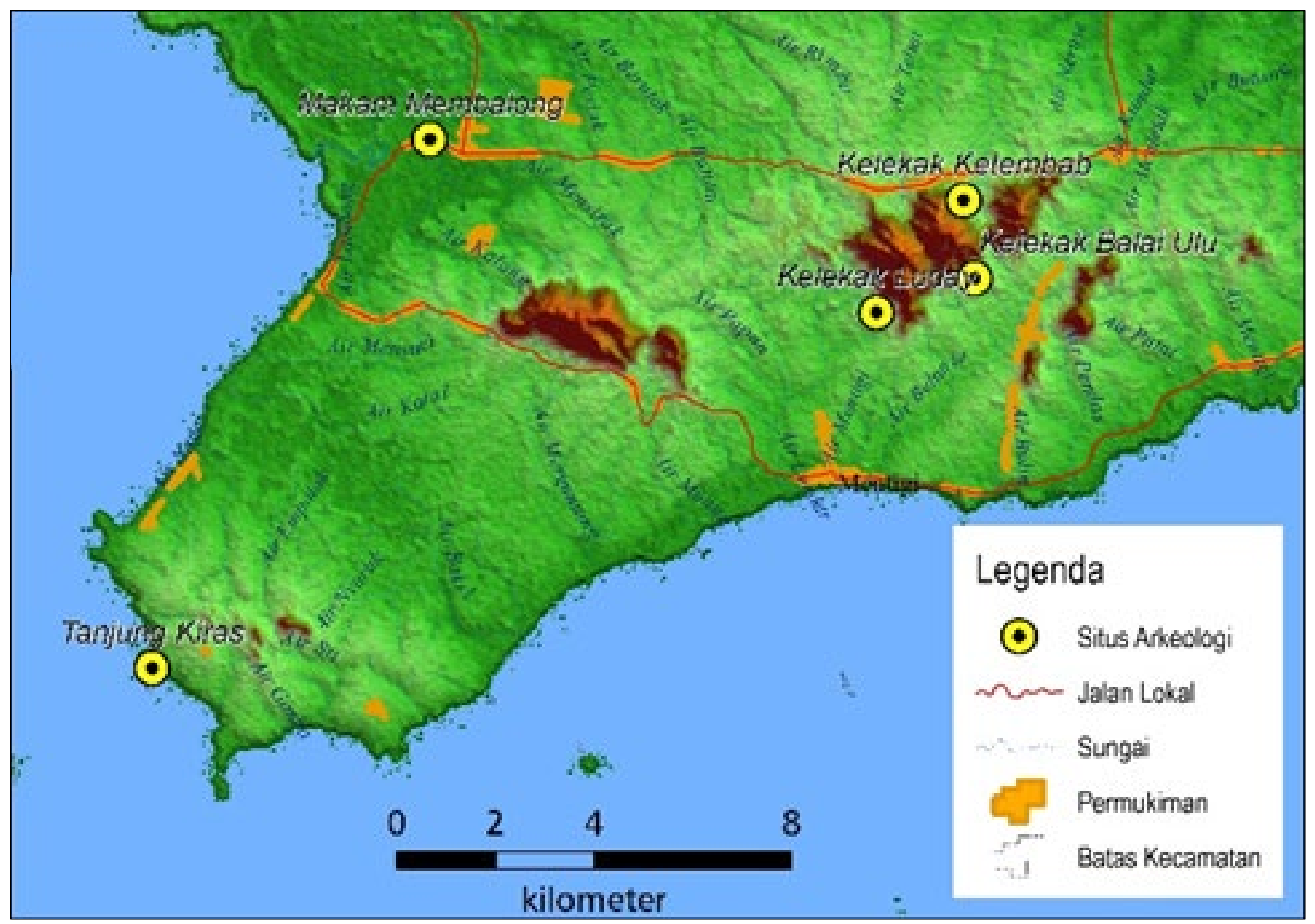

Sumber: Balar Sumsel 2018

Gambar 12 Topografi dan Sebaran Situs Arkeologi di Bagian Selatan Pulau Belitung 
Proses erosi yang terjadi pada batuan granit memberikan pengaruh kuat terhadap terbentuknya mineral timah yang menjadi kekayaan sumber daya di Pulau Belitung. Kandungan bijih timah yang terdapat pada batu granit dikenal sebagai mineral kasiterit. Mineral ini terbentuk dari pengangkatan batuan granit akibat proses erosi dan pelapukan. Proses ini mengakibatkan batuan granit menjadi lunak dan terurai menjadi tanah berpasir hingga terhancurkan kemudian terbawa oleh aliran air ke wilayah yang lebih rendah dan terendapkan di lembah-lembah sungai beserta pasir lainnya yang pada umumnya berupa pasir kuarsa. Wilayah bagian selatan Pulau Belitung umumnya berupa perbukitan yang terbentuk dari susunan batuan granit. Bukit-bukit tersebut juga merupakan hulu dari sungai-sungai yang mengalir di wilayah ini. Aliran sungai-sungai tersebut membawa mineral kasiterit hingga akhirnya mengendap di lembahlembah perbukitan di wilayah bagian selatan Pulau Belitung (Bemmelen 1949a; 1949b).

Pelapukan bukit-bukit granit menjadikannya dapat ditumbuhi berbagai jenis vegetasi. Di wilayah penelitian, terdapat tiga jenis vegetasi alami yaitu: vegetasi Hutan Kerangas Sekunder Tua, Hutan Kerangas Sekunder Muda, dan Padang (Brunig 1974; Whitmore 1984; Whitten dkk. 1997). Pada umumnya, Hutan Kerangas Sekunder Tua dijumpai di bagian-bagian puncak dan lereng atas perbukitan, seperti Gunung Gede, Gunung Luday, Gunung Lia, Bukit Riting, dan Gunung Beluru. Di bagian lereng bawah perbukitan tersebut terdapat Hutan Kerangas Sekunder Muda yang sebagian telah dibudidayakan menjadi kebun oleh masyarakat. Seluruh kelekak ${ }^{1}$ atau ekosistem sukses yang terdapat di wilayah penelitian berada pada morfologi ini. Di wilayah penelitian juga terdapat vegetasi padang yang merupakan ekosistem hutan kerangas yang mengalami disklimaks, sehingga berupa hamparan padang rumput yang sulit untuk tumbuh menjadi hutan kembali.

Situs-situs di pedalaman pada umumnya dijumpai di kawasan yang memiliki vegetasi alami Hutan Kerangas Sekunder Muda. Dalam hutan tersebut banyak kandungan cadangan air tanah dangkal. Hal ini disebabkan wilayah tersebut

\footnotetext{
${ }^{1}$ Istilah lokal untuk menyebut ekosistem suksesi berupa sebidang tanah yang ditanami, baik secara sengaja maupun tidak, oleh orang tua zaman dahulu dengan beragam pohon
}

merupakan bagian dari sabuk mata air di tekuk lereng (slope break) terbawah. Selain itu, di wilayah ini juga banyak, terdapat sungai-sungai kecil, sehingga dapat dikatakan bahwa wilayah ini memiliki cadangan air yang melimpah. Beberapa kelekak yang masih dapat ditemukan di wilayah tersebut diantaranya adalah Kelekak Luday, Kelekak Balai Ulu, dan Kelekak Ketembab (lampiran: Gambar 13). Pada umumnya, di kelekakkelekak tersebut masih dapat dijumpai tanaman yang berorientasi pada konsumsi dan komoditi seperti aren, sahang (lada), kelapa, tanaman buahbuahan, serta tanaman rempah-rempah seperti kunyit, jahe, dan sejenisnya.

Kelekak Luday terletak di sebelah barat daya Gunung Luday. Lokasinya berada di sekitar aliran Sungai Lundar. Topografinya berupa lereng landai sekitar $5-16 \%$ dengan ketinggian antara +38-58 mapl. Kelekak Balai Ulu terletak di sebelah tenggara perbukitan antara Gunung Luday dan Gunung Gede. Kelekak ini berada di antara dua sungai kecil yang merupakan anak dari Sungai Belantu. Topografinya berupa lereng landai sekitar 5-12\% dengan ketinggian antara +46-58 mapl. Kelekak Ketembab berada di sisi timur laut Gunung Gede dan terletak di antara dua aliran sungai kecil yang menjadi anak Sungai Sampai. Topografinya berupa lereng landai cenderung curam antara 9$25 \%$ dan ketinggian antara $+56-80$ mapl.

Satu-satunya situs arkeologi yang terletak di wilayah dengan vegetasi padang adalah Makam Membalong. Di situs ini ditemukan beberapa makam dengan ciri nisan tipe Aceh, dan berbahan batu granit. Namun demikian, ada pula makam yang memanfaatkan botol sebagai nisan. Sekarang, beberapa wilayah vegetasi padang dijumpai menjadi lubang-lubang tambang timah, seperti yang dijumpai di sekitar Desa Mentigi sampai Tanjung Kiras.

Permukiman masyarakat di bagian selatan Pulau Belitung saat ini tumbuh di sekitar perbukitan di antara aliran sungai kecil. Tampaknya pola keletakan kelekak masih diterapkan pada permukiman tersebut, bahkan beberapa permukiman berawal dari suatu kelekak. Permukiman tersebut di antaranya adalah Desa Gunung Riting, Desa Parang Buloh, dan Dusun

penghasil buah-buahan. Kelekak dapat dimiliki secara pribadi melalui garis keturunan, dan ada yang dimiliki secara bersama atau kolektif dalam satu komunitas 
Gunung Kura yang masuk ke dalam wilayah administratif Desa Mentigi. Permukiman tersebut terletak di lereng landai dengan kemiringan antara $3-15 \%$ dengan ketinggian antara $+30-65$ mapl.

Desa Gunung Riting terletak pada lereng landai di sisi barat Gunung Riting. Lokasinya di sekitar aliran Sungai Belantu dan Sungai Bulin, dan memiliki pola linear mengikuti jalan. Desa Parang Buloh terletak di sisi utara Gunung Gede. Wilayahnya berada di sekitar aliran Sungai Tebat dan Sungai Sampai, yang merupakan anak Sungai Kembiri. Dusun Gunung Kura terletak di sebelah selatan Gunung Beluru dan Gunung Kura. Wilayahnya berupa dataran landai yang berada di sekitar aliran Sungai Munun. Semua aliran sungai di antara permukiman tersebut bermuara di bagian selatan Pulau Belitung.

Selain di kaki perbukitan yang landai dan berlokasi jauh dari laut, sejumlah permukiman juga dijumpai di pantai. Beberapa lokasi permukiman tersebut di antaranya Dusun Mentigi, Dusun Batulubang, Dusun Cepun, Dusun Sabong, Desa Padang Kandis, dan Desa Tanjung Rusa. Permukiman yang terletak di pantai ini umumnya berada pada bidang lahan yang datar hingga landai. Sungai tampaknya tidak terlalu menjadi pertimbangan dalam menentukan letak permukiman. Hal ini dikarenakan lokasi tersebut berada di wilayah yang memiliki air tanah dangkal.

\section{Pembahasan}

Secara umum, sebaran situs arkeologi, sebaran kelekak, sebaran permukiman yang ada saat ini serta karakteristik lingkungan fisiknya menunjukkan bahwa strategi subsistensi yang dilakukan masyarakat di bagian selatan Pulau Belitung memiliki pola mengintegrasikan antara kehidupan maritim dan pengolahan lahan pertanian kebun di pedalaman. Pola tersebut hampir sama dengan strategi subsistensi masyarakat di bagian lain pulau Belitung, tetapi dengan ciri-ciri yang sedikit berbeda.

Bagian selatan Pulau Belitung, yang menjadi lokasi penelitian, tidak terdapat sungai-sungai yang besar sebagaimana di wilayah utara. Sungai yang mengalir di wilayah selatan pada umumnya berukuran paling lebar 10 sampai dengan $15 \mathrm{~m}$, dan panjangnya alirannya (ke arah hulu) hanya berkisar $3 \mathrm{~km}$ sampai dengan $5 \mathrm{~km}$. Selain itu, kedalaman sungainya juga relatif dangkal, sehingga hanya dapat dilayari perahu kecil atau sampan. Biasanya, sungai yang dapat menghubungkan pedalaman dengan laut, dengan cara dilayari menggunakan perahu besar, hanya terdapat pada lokasi dengan kemiringan lereng yang datar dan ukuran sungai yang lebar (Braje dkk. 2017).

Hal ini menunjukkan bahwa dalam menjalankan strategi subsistensinya, terutama dalam hal transaksi dengan masyarakat luar, masyarakat di bagian selatan Pulau Belitung cenderung menggunakan akses darat ataupun sampan untuk menghubungkan wilayah di pedalaman dengan wilayah di pesisir. Oleh karena itu, untuk sampai ke laut lepas mereka perlu berganti perahu yang berukuran lebih besar. Alternatif lain adalah mereka tidak memerlukan perahu lain untuk sampai di laut lepas, karena perairan dangkal antarpulau-pulau kecil di selatan Pulau Belitung relatif tenang. Hal ini juga menunjukkan bahwa masyarakat yang bermukim di wilayah pesisir selatan Pulau Belitung lebih mengandalkan kemampuan untuk mengolah lahan pertanian di kelekak serta perikanan pantai, dari sekitar Teluk Balok hingga Tanjung Kiras. Kebiasaan ini menunjukkan perilaku yang berbeda dengan masyarakat yang bermukim di wilayah utara Pulau Belitung, seperti di Sungai Padang (Novita dkk. 2019).

Kondisi perairan di Teluk Balok yang dikelilingi oleh terumbu karang tepi (fringing reef) menunjukkan bahwa perahu yang mampu digunakan di perairan ini harus berbentuk kecil dan ramping. Bentuk perahu seperti itu lebih mampu bergerak bebas hingga mendekati pantai. Selain itu, sungai-sungai yang bermuara di Teluk Balok relatif sempit, sehingga kapal yang berukuran besar tidak mungkin melayari sungai-sungai tersebut (Marriner dan Morhange 2006).

Kondisi perairan dangkal seperti di Teluk Balok ini juga menyebabkan kapal-kapal yang berukuran besar tidak dapat mendekati pantai, melainkan hanya dapat berlayar sampai ke mulut teluk. Perairan di sekitar mulut teluk tersebut relatif lebih dalam dan lebih aman bagi kapal yang berukuran besar dengan lunas yang tinggi, sehingga kapal tersebut terhindar dari jebakan terumbu karang. Berdasarkan kondisi tersebut, maka dapat diduga bahwa transaksi komoditas terjadi di laut, di mana perahu-perahu dari pantai berlayar mendekati kapal-kapal besar tersebut (Skelly dan David 2017). 
Transaksi komoditi dengan masyarakat dari luar tampaknya terjadi di wilayah selatan pulau ini secara langsung, bukan melalui pusat-pusat perekonomian seperti di Kota Tanjungpandan sebagaimana dilakukan masyarakat saat ini. Hal ini dibuktikan dengan adanya situs Pulau Kampak yang diduga merupakan tempat transit barangbarang dari luar sebelum masuk ke dalam Pulau Belitung. Selain itu, tampak pula adanya upaya untuk mendekatkan kapal-kapal besar agar mampu merapat ke daratan dengan pembangunan dermaga di situs Tanjung Kiras. Akan tetapi, sepertinya calon dermaga ini kemungkinan batal dibangun, karena dampak dari berakhirnya Perang Dunia II.

Artefak berupa botol yang ditemukan di sisa kapal karam situs Karang Kennedy juga memiliki karakteristik yang hampir sama dengan temuan botol di situs Pulau Kampak dan Makam Membalong. Jadi, dapat diasumsikan bahwa transaksi komoditi dengan masyarakat luar di bagian selatan Pulau Belitung ini sudah berlangsung pada masa lalu.

Kebutuhan pangan harian masyarakat di bagian selatan Pulau Belitung dapat diperoleh dari sekitar permukiman. Lingkungan di sekitar beberapa situs, yang berupa perairan pantai berkarang, merupakan habitat penting bagi vegetasi air, ikan, dan moluska. Hal ini terlihat pada sisa-sisa kerang dan siput di situs Pulau Kampak yang menunjukkan bahwa sumber pangan tersebut dikumpulkan dari laut yang jaraknya relatif cukup dekat. Hal ini juga terjadi di situs Balai Ulu yang lokasinya cukup jauh dari laut. Di situs Balai Ulu juga ditemukan sisa sampah cangkang kerang laut. Akan tetapi, karena jarak yang cukup jauh dari laut tersebut, menunjukkan bahwa kemungkinan diperlukan sarana transportasi untuk menempuh perjalanan dari lokasi situs ke laut, seperti perahu atau sampan dengan melewati sungai. Berdasarkan kondisi geografisnya, selain perahu, kemungkinan pemukim di situs Balai Ulu juga harus berjalan kaki untuk mencapai sungai terdekat (Aucelli, Mattei, dan Pappone 2016; Costa 2018).

Hasil hutan seperti madu, getah, buahbuahan, tanduk, kulit hewan, dan bahan mineral

\footnotetext{
2 Sering disamakan dengan teminologi exchange yang di dalamnya melibatkan kegiatan perdagangan atau trade menggunakan mata uang atau tanpa mata uang

3 Pengamatan sepintas atas kandungan mineral sejumlah pecahan gerabah dari pulau Kampak memperlihatkan
}

diduga merupakan sumber daya yang dipertukarkan dengan barang-barang yang berasal dari luar pulau. Sumber daya hutan tersebut diperoleh dengan cara berburu dan meramu (Costa 2018; Hansson, Nilsson, dan Svensson 2020; Lancelotti, Pecci, dan Zurro 2017). Barang-barang yang tidak dihasilkan secara lokal menjadi bukti terjadinya pertukaran ${ }^{2}$ yang juga melibatkan faktor jarak dan mobilitas yang lebih kompleks (Skelly dan David 2017). Dengan adanya pertukaran, keramikkeramik dari Cina dan Asia Tenggara, botol dari Eropa, serta gerabah asal Sumatera 3 dapat ditemukan di situs-situs di lokasi penelitian.

Pada saat penelitian berlangsung, di beberapa kelekak terdapat sejumlah jenis tanaman yang masih dimanfaatkan oleh masyarakat sekarang seperti mangga, durian, rotan, damar, aren, kelapa, dan lada. Hal ini menunjukkan bahwa masyarakat yang bermukim di lokasi penelitian pada masa lalu diperkirakan mengkonsumsi tanaman budidaya tersebut. Selain dikonsumsi, kemungkinan tanaman-tanaman tersebut juga dipertukarkan dengan barang-barang impor (Lancelotti dkk. 2017).

\section{PENUTUP}

Secara umum, penelitian ini menggambarkan strategi subsistensi masyarakat yang bermukim di bagian selatan Pulau Belitung pada masa lalu, terutama abad ke-19 M sampai awal abad ke-20 M. Masyarakat di wilayah ini beraktivitas dengan memanfaatkan sumber daya lingkungan di sekitarnya yang dapat dibagi menjadi dua, yaitu lingkungan perairan dan lingkungan darat. Hal ini menunjukkan bahwa kehidupan masyarakat di lokasi penelitian tidak terlepas dari dua ekosistem yang berbeda untuk memenuhi kebutuhan pangannya.

Tinggalan arkeologi berupa benda-benda keramik dan kaca yang ditemukan pada saat penelitian, merupakan barang yang tidak di produksi di wilayah penelitian. Hal ini menunjukkan pernah terjadi perdagangan. Jarak antara konsumen, yaitu penduduk bagian selatan Pulau Belitung, dan komunitas yang memproduksi

adanya unsur pirit (pyrite atau $\mathrm{FeS}_{2}$ ), yaitu sejenis logam tersusun dari unsur besi belerang dengan hasil kegiatan vulkanik yang tidak terdapat di pulau Belitung, ataupun pulau Bangka yang berada di dekatnya 
barang-barang asing tersebut letaknya berjauhan. Dengan kata lain, penduduk bagian selatan Pulau Belitung menjadi kontributor dari sistem perdagangan antarwilayah berjarak jauh. Dengan menggunakan rute perjalanan yang bertahap, produk-produk komoditi tersebut terakumulasi di bagian selatan Pulau Belitung, dan pada akhirnya terdisposisikan sebagai sampah sisa kegiatan penduduk masa lalu.

Kelekak yang merupakan ekosistem ubahan manusia masa lalu meupakan bagian yang tidak terpisahkan dari masyarakat masa kini. Kelekak yang masih dijumpai hingga kini sebagian besar masih dimanfaatkan oleh masyarakat untuk diambil hasilnya. Hal ini menunjukkan bahwa aktivitas masyarakat yang ada pada masa sekarang bisa jadi masih merupakan kelanjutan dari sistem subsistensi yang ada pada masa lalu. Beberapa makam yang terdapat di sekitar kelekak juga dianggap sebagai makam tokoh penting yang memiliki hubungan spiritual dengan masyarakat saat ini.

Transaksi komoditas dengan masyarakat luar yang dahulu pernah terjadi secara langsung di wilayah selatan Pulau Belitung, tampaknya sekarang tidak lagi terjadi. Sebagian besar kebutuhan masyarakat di wilayah ini sekarang bergantung pada pasar barang dan jasa yang ada di Tanjungpandan. Sekarang, Tanjungpandan adalah pusat perekonomian yang paling besar di Pulau Belitung sekaligus satu-satunya pintu masuk barang luar ke dalam pulau ini. Jadi, secara tidak langsung strategi subsistensi masyarakat masa kini sudah jauh berubah, terutama dalam hal perdagangan ataupun pertukaran barang dengan masyarakat luar.

\section{DAFTAR PUSTAKA}

Amato, Vincenzo, Sabatino Ciarcia, Amedeo Rossi, dan Alfonso Santoriello. 2018. "The urban geoarchaeology of Benevento, Southern Italy: Evaluating archaeological potential." Geoarchaeology 33(1):100-111.

Ashari, Arif. 2014. "Distribusi Spasial Mataair Kaitannya dengan Keberadaan Situs Arkeologi di Kaki Lereng Timur Gunung Api Sindoro, antara Parakan dan Ngadirejo." HIm. 169-79 dalam Mega Seminar Nasional Geografi Untuk Mu Negeri. Yogyakarta: Jurusan Pendidikan Geografi Fakultas IImu Sosial, Unviersitas Negeri Yogyakarta.

Ashari, Arif. 2015. "Kearifan Masyarakat Jawa Pra Modern di Lembah Progo Dalam Pengenalan Bentanglahan untuk Lokasi Permukiman: Tinjauan Studi Geoarkeologi." HIm. 366-78 dalam Dilema Membangun Manusia Indonesia: Memilih antara Tuntutan Global atau Kearifan Lokal. Yogyakarta: Fakultas IImu Sosial, Universitas Negeri Yogyakarta.

Aucelli, Pietro, Gaia Mattei, dan Gerardo Pappone. 2016. "Landscape changes along the coasts of Naples Gulf since the Roman times, inferred from new geoarchaeological data." Rend. Online Soc. Geol. It, Suppl 40 (October). Roma: Società Geologica Italiana.

Bachofer, Felix, Geraldine Queneherve, Christine Hertler, Liane Giemsch, Volker Hochschild, dan Michael Maerker. 2018. "Digital
Geoarchaeology." Digital Geoarchaeology 123-38.

Bade, David W. 2002. Khubilai Khan and the Beautiful Princess of Tumapel: the Mongols Between History and Literature in Java. Ulaanbaatar: A. Chuluunbat.

Baharuddin dan Sidarto. 1995. Peta Geological Bersistem Indonesia: Lembar Belitung Sumatra 1212, 1213, 1312, 1313 Skala 1:250.000. Bandung: Pusat Penelitian dan Pengembangan Geologi.

Braje, Todd J., Thomas P. Leppard, Scott M. Fitzpatrick, dan Jon M. Erlandson. 2017. "Archaeology, historical ecology and anthropogenic island ecosystems." Environmental Conservation 44(3): 286-297.

Brunig, E.F. 1974. Ecological Studies in The Kerangas Forests of Sarawak and Brunei. Kuala Lumpur: Borneo Literature Bureau.

Butzer, Karl. W. 2006. Archaeology as human ecology: Method and theory for a contextual approach. Cambridge University Press.

Christiansen, Anders Vest, Jesper Bjergsted Pedersen, Esben Auken, Niels Emil Søe, Mads Kähler Holst, dan Søren Munch Kristiansen. 2016.2 "Improved geoarchaeological mapping with electromagnetic induction instruments from dedicated processing and inversion." Remote Sensing 8(12). 1-15. 
Contreras, Daniel A. 2017. "(Re)constructing the sacred: Landscape Geoarchaeology at Chavín de Huántar, Peru." Archaeological and Anthropological Sciences 9 (6):1045-1057.

Costa, Diogo M. 2018. "Eco-historical archaeology in the Brazilian Amazon: Material, Natural and Cultural Western Transformations." Historical Archaeology and Environment: 65-86.

Erman, Erwiza. 2009. Dari Pembentukan Kampung ke Perkara Gelap Menguak Sejarah Timah Bangka-Belitung. Yogyakarta: Ombak.

Fahmi, Rezza Fauzi Muhammad, Gugun Gunardi, dan Dade Mahzuni. 2017. "Fungsi dan Mitos Upacara Adat Nyangku di Desa Panjalu Kecamatan Panjalu Kabupaten Ciamis." Panggung 27(2): 201-216.

Fahmi, Ridzky Firmansyah. 2017. "Mitos Danau sebagai Pelestari Lingkungan." Deiksis 4(2).

Fitrahayunitisna. 2019. "Kesadaran Ekologi dalam Mitos Di Telaga Rambut Monte, Desa Krisik Kecamatan Gandusari Kabupaten Blitar." Jurnal Studi Budaya Nusantara 3(1):40-51.

French, Charles. 2003. Geoarchaeology in Action: Studies in soil micromorphology and landscape evolution. New York: Routledge Taylor \& Francis Group.

Giaime, Matthieu, Nick Marriner, dan Christophe Morhange. 2019. "Evolution of ancient harbours in deltaic contexts: A geoarchaeological typology." Earth-Science Reviews 191(January):141-67.

Goldberg, Paul dan Vera Aldeias. 2018. "Why does (archaeological) micromorphology have such little traction in (geo)archaeology?" Archaeological and Anthropological Sciences 10(2): 269-278.

Groeneveldt, Willem Pieter. 2018. Nusantara dalam Catatan Tionghoa. Depok: Komunitas Bambu.

Hansson, Martin, Pia Nilsson, dan Eva Svensson. 2020. "Invisible and Ignored: The Archaeology of nineteenth century subalterns in Sweden." International Journal of Historical Archaeology 24(1) 1-21.

Kelley, Alice R. dan David Sanger. 2017. "Holistic geoarchaeology in the Penobscot Valley, Maine, USA: context, scale, and interpretation." Archaeological and Anthropological Sciences 9(8):1627-1644.

Key, Marcus M., Spencer B. Lieber, dan Robert J. Teagle. 2020. "An Historical Geoarchaeological Approach to Sourcing an
Eighteenth Century Building Stone: Use of Aquia Creek Sandstone in Christ Church, Lancaster County, VA, USA." Geoheritage 12(1) 1-14.

Kidder, Tristram R. dan Haiwang Liu. 2017. "Bridging theoretical gaps in geoarchaeology: archaeology, geoarchaeology, and history in the Yellow River valley, China." Archaeological and Anthropological Sciences 9(8):1585-1602.

Lancelotti, Carla, Alessandra Pecci, dan Debora Zurro. 2017. "Anthropic Activity Markers: Archaeology and Ethnoarchaeology." Environmental Archaeology 22(4):339-342.

Marriner, Nick dan Christophe Morhange. 2006. "Geoarchaeological evidence for dredging in Tyre's ancient harbour, Levant." Quaternary Research 65(1):164-171.

Mus, Aliong. 2016. "Pembangunan Berbasis Kearifan Lokal di Pulau Taliabu: Potensi Dan Aktualisasinya Bagi Pembangunan Daerah." Etnohistori 2(1):79.

Novita, Aryandini, Junus Satrio Atmodjo, Dadang $\mathrm{H}$. Purnama, dan Jepriadi A. Lumbu. 2019. "Pola Hubungan Maritim Situs-situs di Daerah Aliran Sungai Padang, Kecamatan Sijuk, Kabupaten Belitung pada Awal Abad XX." Laporan Penelitian Arkeologi. Palembang: Balai Arkeologi Sumatera Selatan.

Novita, Aryandini, Junus Satrio Atmodjo, Dadang H. Purnama, Yanto H. M. Manurung, Ari Mukti Wardoyo Adi, dan Jepriadi A. Lumbu. 2018. "Penelitian Arkeologi Maritim. Peran Pulau Belitung Bagian Selatan dalam Jalur Perdagangan dada Awal Abad XX." Laporan Penelitian Arkeologi. Palembang: Balai Arkeologi Sumater Selatan.

Ode, La, Muhadjirin Sahida, dan Wa Ode Sifatu. 2001. "Persepsi Masyarakat terhadap Air Matakidi (studi di Desa Mata Kidi, Kecamatan Lawa)." Etnoreflika 7(1):42-49.

Pradjoko, Didik dan Bambang budi Utomo. 2013. Atlas Pelabuhan-Pelabuhan Bersejarah di Indonesia. diedit oleh E. Djaenuderadjat. Jakarta: Direktorat Sejarah dan Nilai Budaya, Direktorat Jenderal Kebudayaan, Kementerian Pendidikan dan Kebudayaan.

Priem, H.N.A., N.A.I.M. Boelwijk, E.A.T. Hebedd, Verdurmen, dan R. Verschure. 1975. "Isotope Geochronology in the Indonesia Tin Belt." Geol. en Mijnb 54(1): 61-70. 
Puspawati, Luh Putu. 2016. "Pelestarian Lingkungan Hidup dan Mitos Sapi di Desa Tambakan, Kubutambahan, Buleleng." Vidya Shamita Jurnal Penelitian Agama 2(1): 36-43.

Raharja, Randy, Faisal Grahadi Wibowo, Riski Vitria Ningsih, dan Sari Viciwati Machdum. 2016. "Peran Kearifan Lokal Dalam Penanggulangan Bencana (Studi Kasus Tanggap Darurat Banjir 2013, 2014, 2015)." Jurnal Dialog Penanggulangan Bencana 7(2):110-119.

Romadhona, Meggi. 2016. "Jejak Laut Holosen di Pulau Belitung." Geomagz, September, 78-83.

Roos, Christopher I. dan E. Christian Wells. 2017. "Geoarchaeology of ritual behavior and sacred places: an introduction." Archaeological and Anthropological Sciences 9(6):1001-1004.

Skelly, Robert John dan Bruno David. 2017. Hiri: archaeology of long-distance maritime trade along south coast of Papua New Guinea. Honolulu: University of Hawai'i Press.

Storozum, Michael J., Junna Zhang, Hui Wang, Xiaolin Ren, Zhen Qin, dan Lan Li. 2019. "Geoarchaeology in China: Historical Trends and Future Prospects." Journal of Archaeological Research 27(1):91-129.

Suprapto, Sabtanto Joko. 2008. "Potensi, Pengusahaan dan Prospek timah putih di Indonesia." Buletin Sumber Daya Geologi $3(2): 4-15$.

Vlekke, Bernard H.M. 2008. Nusantara Sejarah Indonesia. Terjemahan. Jakarta: Kepustakaan Populer Gramedia.

Volkmann, Armin. 2018. "Methods and Perspectives of Geoarchaeology Site Catchment Analysis: Identification of Palaeoclimate Indicator in the Oder Region from The Iron to Middle Ages." HIm. 123-38 in Digital Geoarchaeology. Cham, Switzerland:
Springer Nature

Wardani, Winny Gunarti Widya, Wulandari Wulandari, Rezha Destiadi, dan Syahid Syahid. 2019. "Representasi Interaksi Manusia dalam Genre Fotografi 'Story' Situs Megalitikum Gunung Padang." Jurnal Muara IImu Sosial, Humaniora, dan Seni 3(1):148.

Whitmore, T. C. 1984. Tropical Rainforest of the Far East. 2nd ed. Oxford: Clarendon Press.

Whitten, Tony, Sengli J. Damanik, Jazanul Anwar, dan Nazarudin Hisyam. 1997. The Ecology of Sumatra. Hongkong: Periplus Editions Ltd.

Wijonarko, Wisnu Wahyu, Bandi Sasmito, dan Arief Laila Nugraha. 2016. "Kajian Pemodelan Dasar Laut Menggunakan Side Scan Sonar dan Singlebeam Echosounder." Jurnal Geodesi Universitas Diponegoro 5(2):168178.

Yanti, Rinda dan Hasan Ibrahim. 2018. "Kajian Sosiologi Perilaku Konservasi dengan Wanatani Wilayah Semi Arid Khatulistiwa (Studi Kasus: di Kecamatan Amarasi, Nusa Tenggara Timur)." Journal of Applied Agricultural Science and Technology 2(2): 5570.

van Bemmelen, R.W. 1949a. The Geology of Indonesia Vol. 1A: General Geology of Indonesia. The Hague: Martinus Nijhoff.

van Bemmelen, R. W. 1949b. The Geology of Indonesia Vol. 2: Economic Geology. The Hague: Martinus Nijhoff.

van Zuidam, Robert A. 1979. Terrain Analysis and Classification Using Aerial Photographs: A Geomorphological Approach. Enschede: International Institute for Aerial Survey and Earth Sciences.

Zuriyani, Elvi. 2016. "Dinamika Kehidupan Manusia dan Kondisi Sumberdaya Alam Daerah Aliran Sungai." Jurnal Spasial 3(2): 54-74. 
Aspek Geoarkeologi Terhadap Strategi Subsistensi Masyarakat di Pesisir Selatan Belitung dari Abad Ke-19 Sampai Awal Abad Ke20 Masehi- Aryandini Novita dan Ari Mukti Wardoyo Adi (155-168)

Doi: $10.24832 / n w . v 14 i 2.425$

\section{LAMPIRAN}

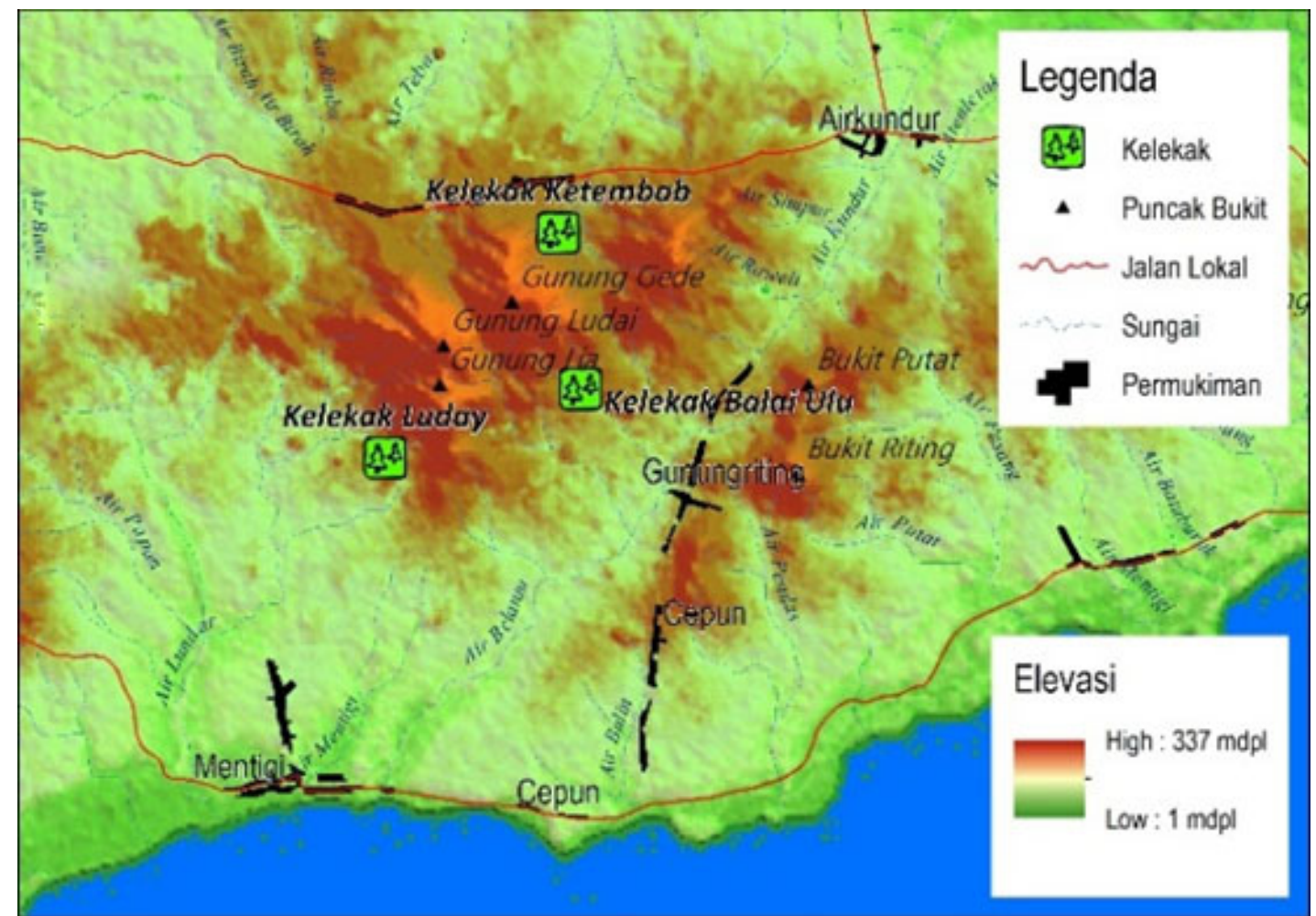

Sumber: Balar Sumsel 2018

Gambar 13 Topografi dan Sebaran Kelekak di Bagian Selatan Pulau Belitung

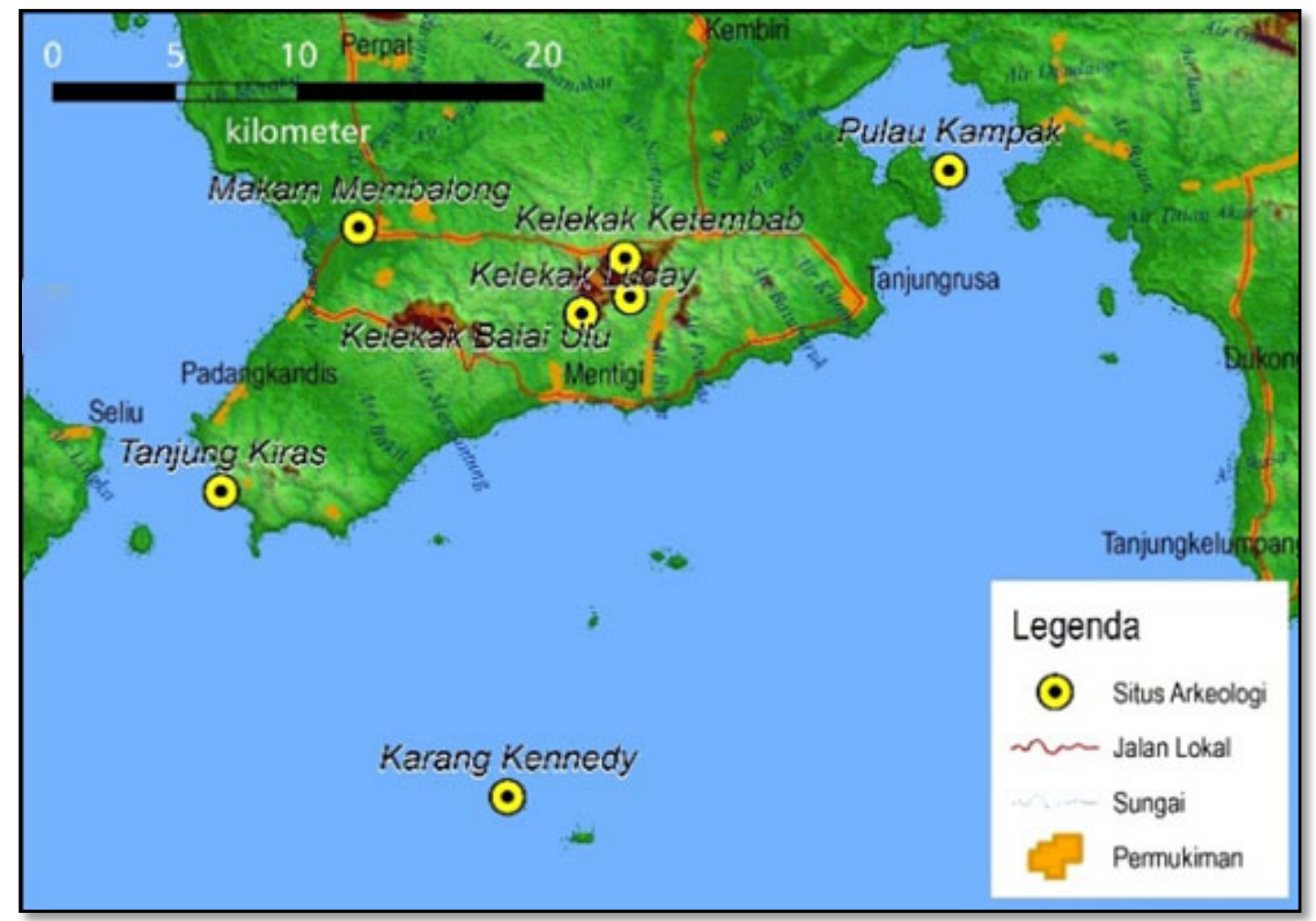

Sumber: Balar Sumsel 2018

Gambar 14 Persebaran Situs di Pulau Belitung Bagian Selatan 